\title{
Utilization of gypsum from construction and demolition waste in Portland cement mortar
}

\author{
M. L.P. Antunes ${ }^{1 *}$, A. Botignon de Sá $a^{1}$, P. S. Oliveira ${ }^{1,2}$, E. C. Rangel ${ }^{1}$ \\ ${ }^{I}$ São Paulo State University (UNESP), Institute of Science and Technology, Sorocaba, \\ Av. Três de Março 511, 18087-180, Sorocaba, SP, Brazil \\ ${ }^{2}$ Universidade de Sorocaba, Sorocaba, SP, Brazil
}

\begin{abstract}
Civil construction generates the largest amount of construction and demolition waste (CDW), most of which is not reused and is discarded as inert waste in landfills. The purpose of this study was to evaluate the feasibility of reusing gypsum recovered from CDW in the preparation of mortar. This material was examined to determine its specific mass, morphology, elemental composition and particle size distribution. Test specimens were prepared with a mix design of 1:3 (cement:sand), with the gypsum waste substituting part of sand in proportions of $0,10,20$ and 30\% (in volume). The consistency of the fresh mortar was evaluated: the specimens were tested to determine their flexural and compressive strength, apparent density, water absorption, voids index, and specific mass. After 28 days, the mechanical strength of the specimens exceeded the limits specified by NBR 13281 standard, indicating that up to $30 \%$ of ground gypsum waste can be included in a mortar.
\end{abstract}

Keywords: construction and demolition waste, gypsum, mortar, Portland cement.

\section{INTRODUCTION}

Civil construction, one of humanity's oldest activities, is also an indicator of a country's social and economic growth. However, closely associated with this activity is the intense exploitation of natural resources and the generation of large amounts of mineral wastes or debris, also called construction and demolition waste (CDW). According to Brazil's national solid waste policy [1], CDW is defined as waste generated during the construction, remodeling, repair or demolition of civil construction works, including waste resulting from the preparation and excavation of land for civil works. CDW has become a major problem for Brazilian municipalities, requiring ever more space for landfills, since it represents $50 \%$ or more of the volume of urban solid wastes [2]. CDW is often illegally dumped on vacant lots, along river banks and other sites, damaging the environment and impairing the health of the population. However, CDW can be used to save natural resources, employing it for a more suitable purpose. The first large-scale use of construction waste was recorded in the post-war period, when it was crushed and used as construction aggregates to help rebuild European cities [3]. Current Brazilian legislation [4] requires those who generate construction and demolition waste to assume responsibility for managing it. This has led large CDW generators to begin separating their CDW into different classes, allowing it to be reused, recycled or discarded properly. This practice has encouraged the research and development of technologies that enable CDW to be used as raw material at the same construction sites where it is generated.

*malu@sorocaba.unesp.br

(D) https://orcid.org/0000-0002-0503-9284
Among the wide variety of CDW is gypsum, a material that is being increasingly used by civil construction in various applications, including suspended ceilings (plasterboard ceilings), precast moldings (crown moldings, decorative moldings and trim), plasterboard, inner wall linings, etc. [5, 6]. According to ABRAGESSO (Brazilian Association of Drywall Producers) [7], about 12000 tons/year of gypsum waste is generated in the Greater São Paulo. Resolution No. 307/2002 of CONAMA (National Environmental Agency) [4] classifies gypsum as class C material, in other words, "construction and demolition waste for which no economically feasible technologies or applications have been developed to allow for its recycling or recovery". However, when improperly discarded, this waste generates sulfuric gas, which is toxic and flammable [5]. To reduce the amount of gypsum waste sent to landfills, even to inert waste landfills, recycling techniques have therefore been improved and gypsum is being reused, leading to its reclassification as class $\mathrm{B}$ waste [8], boosting the creation of new technologies for its use and of gypsum recycling companies. In Europe [9] and Canada [10], large companies have used recycled gypsum in the production of drywall. This is feasible because gypsum that is separated from other wastes, i.e., uncontaminated, can be crushed and calcined to recover its binding ability [6] Recent studies $[5,10,11]$ have used recycled and calcined gypsum to obtain gypsum paste for internal coatings, and have described the factors that may influence the physical and mechanical properties of this mortar. The purpose of this study was to find an alternative way to reduce the cost of using this type of CDW, by eliminating the calcination step. This paper presents the results and properties of a cement mortar prepared with part of the fine aggregate substituted by crushed gypsum waste, eliminating the need for calcination. 


\section{EXPERIMENTAL}

Collection and characterization of the waste: the gypsum waste used in this study came from ceiling plasterboard installed during residential and industrial renovations. The plasterboards were made of one layer of gypsum and one of polystyrene board, and weighed approximately $4 \mathrm{~kg}$. In order to use this waste in the mortar mix, the styrofoam was removed and the gypsum was then crushed into powder. This was done manually, using a metal shredder. The gypsum powder was analyzed to determine its specific mass, using the technique described in [12]. The gypsum particle size distribution was also analyzed, as described by the NBR 7214 standard [13], in order to compare it with that of the sand normally used in civil construction. The particle morphology was analyzed by scanning electron microscopy (SEM, Jeol JSM-6010), while the elemental chemical composition of the material was investigated using energy dispersive X-ray spectroscopy (EDS coupled to SEM), which revealed the characteristics of the CDW.

Preparation and molding of mortars: before preparing the mortar containing gypsum waste, the materials, i.e., medium sand, CPII F-32 cement (Votoran) and waste, were oven-dried at $50{ }^{\circ} \mathrm{C}$ for $72 \mathrm{~h}$ to completely eliminate their moisture. The mix design was 1:3:1 (cement:sand:water), and the mortars were prepared in a $5 \mathrm{~L}$ mortar mixer, as specified by the Brazilian standards NBR 16541 and 7215 [14, 15]. The sand was substituted for gypsum powder in volumetric proportions of 10,20 and 30\%, and a waste-free mortar $(0 \%)$ was also prepared. The mortars were characterized to determine their consistency, according to NBR 13276 [16], using a vibrating table as described in NBR 7215 [15] to evaluate the influence of the gypsum waste on the mortar workability [16]. After evaluating the consistency index, the mortars were placed in three-gang molds for mortar prisms 40x40x160 mm, as specified by NBR 13279 [17]. To ensure reproducibility and to calculate the standard deviation in the characterization tests, six test specimens were cast for each composition and curing time (14 and 28 days). The cast test specimens were demolded after $48 \mathrm{~h}$ and stored in a suitable place until they were subjected to mechanical strength tests.

Characterization of test specimens: the apparent density (d) $\left[\mathrm{kg} / \mathrm{m}^{3}\right]$ of the test specimens was determined after 14 and 28 days of curing, by measuring the mass (ma) $[\mathrm{kg}]$ and the height $(\mathrm{x})$, width (y) and length $(\mathrm{z})[\mathrm{m}]$ of the test specimens, as specified by the Brazilian standard NBR 13280 [18], and calculated according to:

$$
\mathrm{d}=\frac{\mathrm{ma}}{\mathrm{x} \cdot \mathrm{y} \cdot \mathrm{z}}
$$

Flexural and compressive strength tests were also performed, as specified by NBR 13276 [16], using a hydraulic press (ViaTest, Brazil) equipped with the appropriate devices described in the standard, in order to measure the strength [MPa] of the prepared mortars after 14 and 28 days of curing. The results of the apparent density, flexural and compressive strength tests at 28 days were compared with the NBR 13281 standard [19], which establishes mechanical strength parameters and classifies mortars based on their physical characteristics. In addition, the results were analyzed statistically by analysis of variance, ANOVA [20], using the data analysis tool in MS Excel, which verified the hypothesis of equality between the means of the evaluated results $\left(\mathrm{H}_{0}:\right.$ mean $_{1}=$ mean $_{2}=\ldots$ $=$ mean $\left._{n}\right)$ or rejected the equality between means $\left(\mathrm{H}_{1}\right.$ :there is a difference), indicating that there was at least one difference between the results, at a significance level $(\alpha)$ of $5 \%$. The ANOVA calculations were the sum of squares (SS), degrees of freedom (DF), and mean squares (MS), which were used to calculate the F-statistic, which was then compared with the tabulated value, Snedecor's F or the $F_{\text {critical }}$ value, to determine the significance or lack thereof. When hypothesis $\mathrm{H}_{1}$ was statistically confirmed, Tukey's test $[20,21]$ was applied. This test evaluated the level of significance $(\alpha=0.05)$ of each result of the sample group, indicating the statistically significant and non-significant differences between the means. This analysis was performed using Origin 8.6 software. To determine the voids index (VI), water absorption (WA), and density of the test specimens in the dry state $\left(\varrho_{d}\right)$ and water-saturated state $\left(\varrho_{\text {sat }}\right)$, the tested specimens were first oven-dried for $72 \mathrm{~h}\left(\mathrm{M}_{\mathrm{s}}\right)$. They were then weighed and soaked in water for $72 \mathrm{~h}$, after which they were weighed again on an analytical balance $\left(\mathrm{M}_{\mathrm{sat}}\right)$ and on a hydrostatic balance $\left(\mathrm{M}_{\mathrm{I}}\right)$. This procedure was performed according to NBR 9778 [22]. Based on the measured weights [g], the VI [\%], WA [\%], $\varrho_{d}\left[\mathrm{~g} / \mathrm{cm}^{3}\right]$, and $\varrho_{\text {sat }}\left[\mathrm{g} / \mathrm{cm}^{3}\right]$ were then calculated using Eqs. B, C, D, and E, respectively:

$$
\begin{aligned}
& \mathrm{VI}=\frac{\mathrm{M}_{\mathrm{sat}}-\mathrm{M}_{\mathrm{S}}}{\mathrm{M}_{\mathrm{sat}}-\mathrm{M}_{\mathrm{I}}} .100 \\
& \mathrm{WA}=\frac{\mathrm{M}_{\mathrm{sat}}-\mathrm{M}_{\mathrm{s}}}{\mathrm{M}_{\mathrm{s}}} .100 \\
& \rho_{\mathrm{d}}=\frac{\mathrm{M}_{\mathrm{s}}}{\mathrm{M}_{\mathrm{sat}}-\mathrm{M}_{\mathrm{I}}} \\
& \rho_{\mathrm{sat}}=\frac{\mathrm{M}_{\mathrm{sat}}}{\mathrm{M}_{\mathrm{sat}}-\mathrm{M}_{\mathrm{I}}}
\end{aligned}
$$

\section{RESULTS AND DISCUSSION}

Characterization of the waste: the gypsum waste presented a specific mass of $1.10 \pm 0.01 \mathrm{~g} / \mathrm{cm}^{3}$, i.e., lower than that of sand, which is $2.6 \mathrm{~g} / \mathrm{cm}^{3}$ [23], indicating the possibility of the lower density of mortars containing this waste. As can be seen in Fig. 1a, the gypsum powder had a $\beta$-type morphology of irregular shaped porous crystals [24]. Fig. 1b shows the elemental chemical composition of the powder, determined by EDS/SEM, in which three elements were identified, $\mathrm{Ca}, \mathrm{S}$ and $\mathrm{O}$, in accordance with the gypsum $\left(\mathrm{CaSO}_{4}\right)$ formula [24], indicating that the waste contained no contaminants. As can be seen from the granulometric analysis of the powder shown in Fig. 1c, the crushing process 

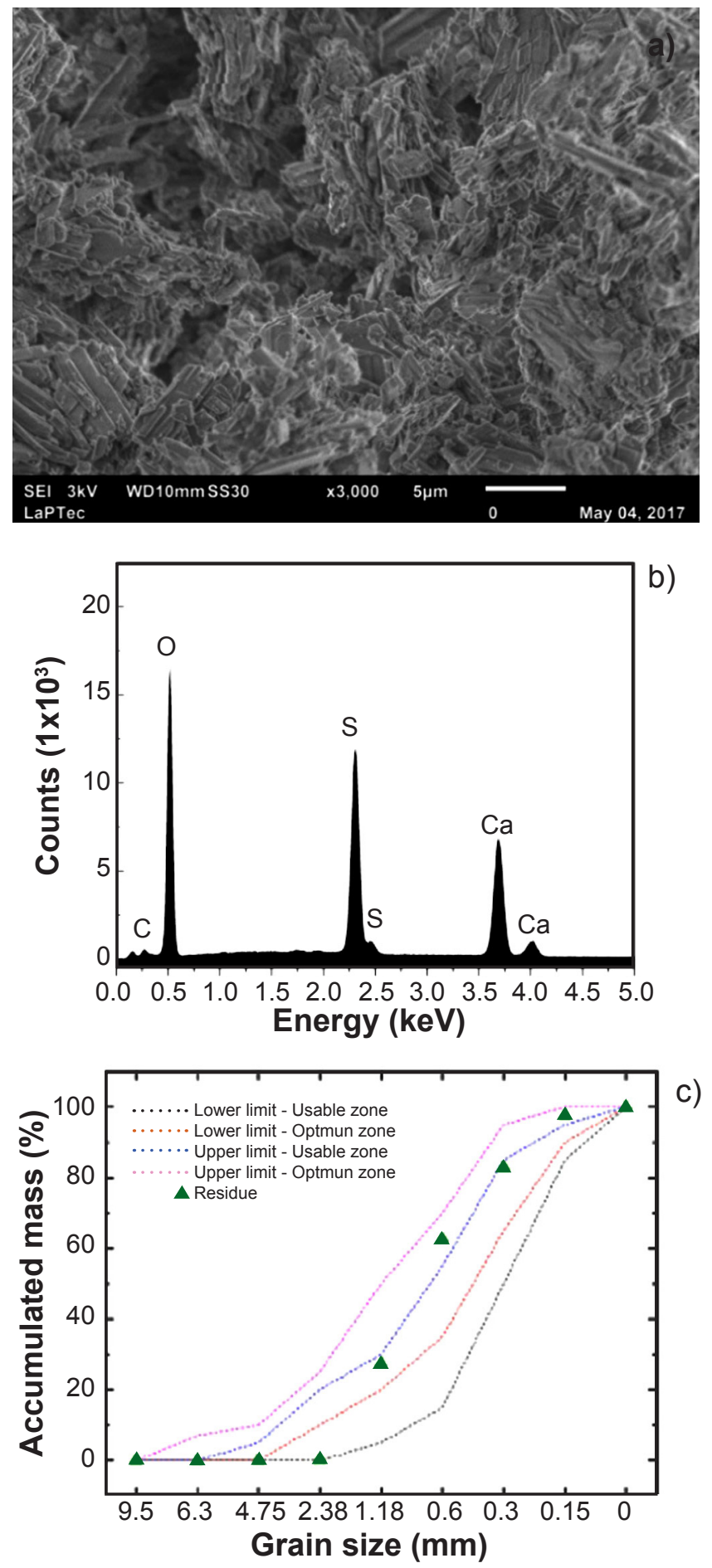

Figure 1: SEM micrograph (a), EDS spectrum (b), and particle size distribution curve (c) of the gypsum powder.

used to obtain the powder generated particles whose size distribution was within the range specified by NBR 7214 [13], thus validating its use replacing sand for the production of mortars.

Preparation of the mortars: Fig. 2 presents the consistency index of all the mortars produced, i.e., containing 0 to $30 \%$ of gypsum replacing sand. Note that increasing the percentage of gypsum waste mixed into the mortar caused its consistency index to increase, and that the consistency index of the sample without waste was 215 $\mathrm{mm}$, while that of the sample containing 30\% of gypsum was approximately $245 \mathrm{~mm}$. This can be attributed to the fact that gypsum particles are smoother than medium sand particles, compared according to NBR 7414 [13]. This greater smoothness favored water absorption during the preparation of mortar [25], increasing its workability while still remaining within the limit specified by NBR 16541 [14], which is $260 \mathrm{~mm}$.

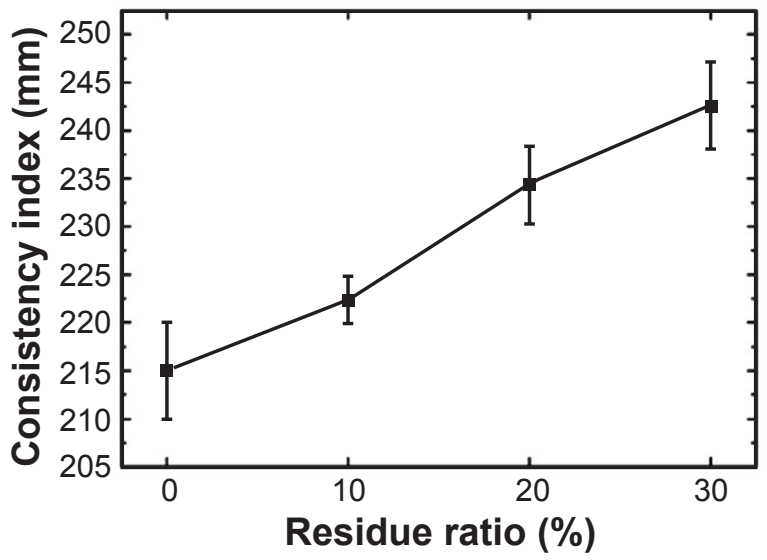

Figure 2: Consistency index of mortars.

Characterization of the test specimens: as can be seen in Fig. 3 , at 14 and 28 days, all the mortars showed an apparent density classified as category M6 (above $1800 \mathrm{~kg} / \mathrm{m}^{3}$ ), in conformity with NBR 13281 [19]. Note that, at 28 days, the test specimens with $30 \%$ waste content presented a mass reduction of approximately $5 \%$ when compared to the wastefree test specimens. However, the analysis of variance of the apparent densities in the hardened state (Table I) indicated that the $F$ value was lower than the $F_{\text {critical }}$ value, indicating that the difference in the values of the analyzed samples was non-significant, i.e., from a statistical standpoint, there was no reduction in apparent density when waste was used as a substitute for sand.

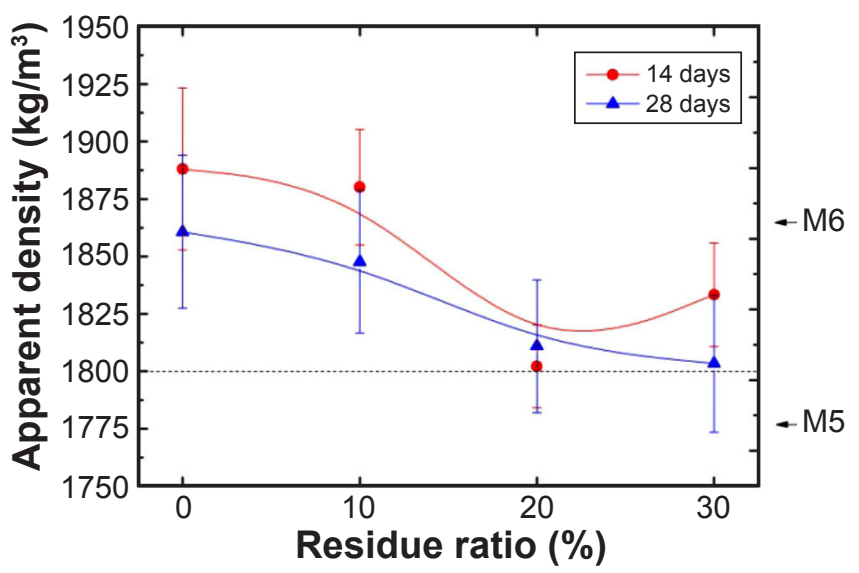

Figure 3: Apparent density of the samples in the hardened state.

The flexural tensile strength (Fig. 4a) increased with the 
Table I - Results of analysis of variance of apparent density at 28 days.

\begin{tabular}{lccccc}
\hline Source of variation & SS & DF & MS & F & $\mathrm{F}_{\text {critical }}$ \\
\hline Among groups & 6982.45 & 3.00 & 2327.48 & 2.46 & 4.07 \\
Within groups & 7583.02 & 8.00 & 947.88 & & \\
Total & 14565.47 & 11.00 & & & \\
\hline
\end{tabular}

curing time of 14 to 28 days, indicating that the cement was hydrated with the use of 0 to $30 \%$ of gypsum replacing sand [26]. At 28 days, all the samples exceeded the maximum classification (R6) established by NBR 13281 [19], i.e., above $4.5 \mathrm{MPa}$, indicating the feasibility of using this waste in construction, based on this criterion. The flexural tensile strength of the mortars containing 10 to $30 \%$ of gypsum replacing sand was found to be higher than or equal to that of the gypsum-free mortar, although this was not observed at 14 days of curing. The increase in mechanical strength at 28 days when compared to that at 14 days can be explained by the fact that the test specimens containing 10 to $30 \%$ of gypsum showed a higher consistency index (Fig. 2). In other words, their free water content was higher, which was corroborated by the delayed curing of these samples, and hence, the hydration of their cement content and greater mechanical strength [26]. The analysis of variance of the
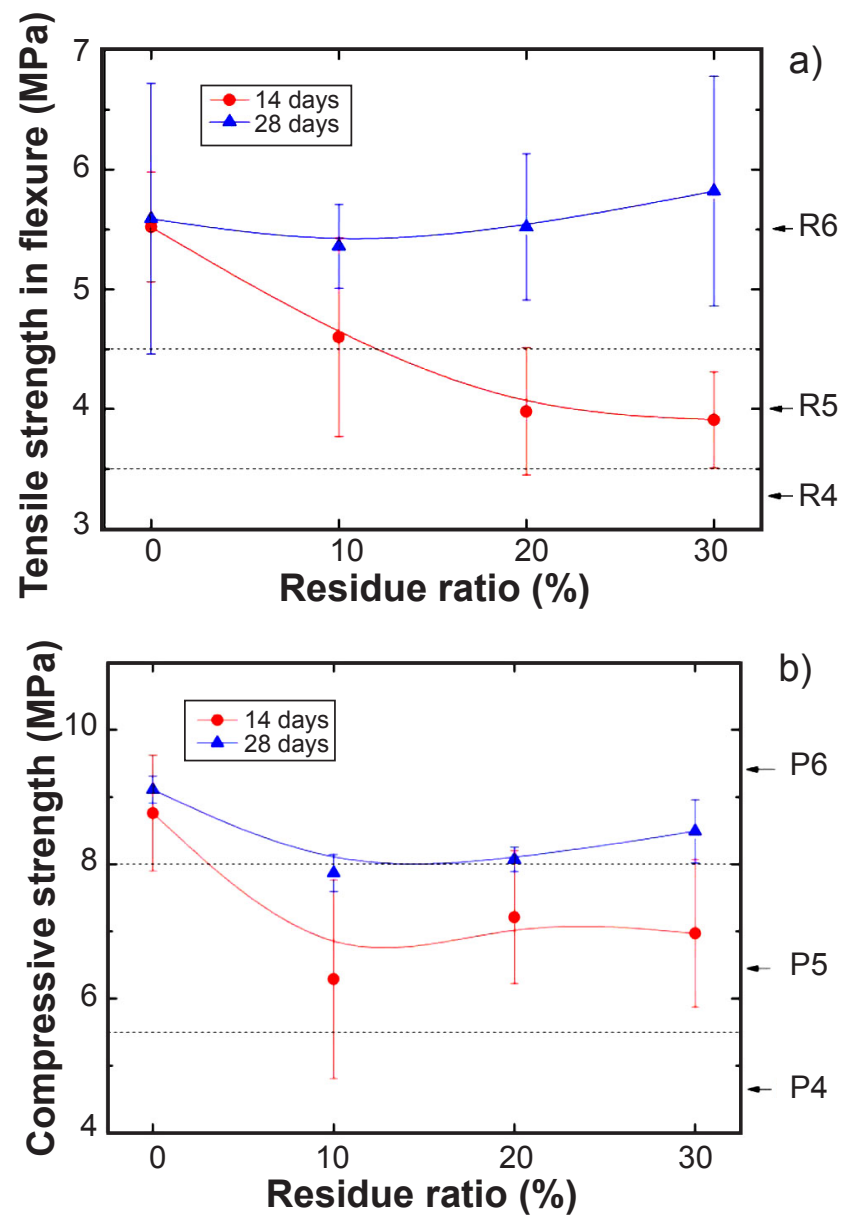

Figure 4: Flexural tensile (a) and compressive (b) strengths of the samples cured for 14 and 28 days.
Table II - Results of analysis of variance of flexural tensile and compressive strengths at 28 days.

\begin{tabular}{cccccc}
\hline Source of variation & $\mathrm{SS}$ & $\mathrm{DF}$ & $\mathrm{MS}$ & $\mathrm{F}$ & $\mathrm{F}_{\text {critical }}$ \\
\hline \multicolumn{7}{c}{ Flexural tensile strength } \\
Among groups & 0.33 & 3.00 & 0.11 & 0.16 & 4.07 \\
Within groups & 5.39 & 8.00 & 0.67 & & \\
Total & 5.72 & 11.00 & & & \\
\hline \multicolumn{7}{c}{ Compressive strength } \\
Among groups & 2.72 & 3.00 & 0.91 & 10.39 & 4.07 \\
Within groups & 0.70 & 8.00 & 0.09 & & \\
Total & 3.42 & 11.00 & & & \\
\hline
\end{tabular}

flexural tensile strengths (Table II) indicated that the F value was lower than the $\mathrm{F}_{\text {critical }}$ value, confirming that there was no statistically significant difference in the flexural tensile strength of the analyzed samples when sand was substituted for gypsum.

The compressive strength (Fig. 4b) also confirmed that the cement was hydrated, since the mechanical strength of the samples at 28 days was higher than at 14 days [26]. Moreover, given that at 28 days they showed values exceeding the maximum compressive strength (P6) of 8 MPa established by NBR 13281 [19], this also indicated the feasibility of using gypsum waste in mortar mixes. The analysis of variance of the compression strengths (Table II) indicated that the $F$ value was higher than the $\mathrm{F}_{\text {critical }}$ value, demonstrating that, among the analyzed samples, at least one value presented a significant difference. Table III lists the results of the Tukey test of the compressive strength analysis of the test specimens at 28 days. As can be seen, when compared to the specimens without gypsum, all the specimens containing gypsum in partial substitution of sand showed a significant decrease in mechanical strength, i.e., in statistical terms, the gypsum waste affected the strength evaluated by this criterion, reducing it. The only exception was the specimen containing $30 \%$ of waste, whose results were not non-significant when compared to the specimen without gypsum. However, a comparison of the specimen containing $30 \%$ of gypsum against those containing different proportions showed no significance, i.e., the test specimens with $10 \%$ to $30 \%$ gypsum content were statistically equal and the non-significance, when compared to the specimen without gypsum waste, was due to the standard deviation of the specimen with $30 \%$ gypsum content.

Fig. 5a illustrates the results of the analysis of void index and water absorption. Upon comparing the test specimens 
Table III - Results of Tukey's test of compressive strength at 28 days.

\section{Comparison}

\begin{tabular}{cccc}
$\overline{\mathrm{x}}_{\mathrm{a}}$ & $\overline{\mathrm{x}}_{\mathrm{b}}$ & $\left|\overline{\mathrm{x}}_{\mathrm{a}}-\overline{\mathrm{x}}_{\mathrm{b}}\right|$ & Conclusion \\
\hline 0.0 & 10.0 & 1.2 & Statistically significant \\
0.0 & 20.0 & 1.0 & Statistically significant \\
0.0 & 30.0 & 0.6 & Non-significant \\
10.0 & 20.0 & 0.2 & Non-significant \\
10.0 & 30.0 & 0.6 & Non-significant \\
20.0 & 30.0 & 0.4 & Non-significant \\
\hline Note: minimum significant difference $=0.8$ &
\end{tabular}
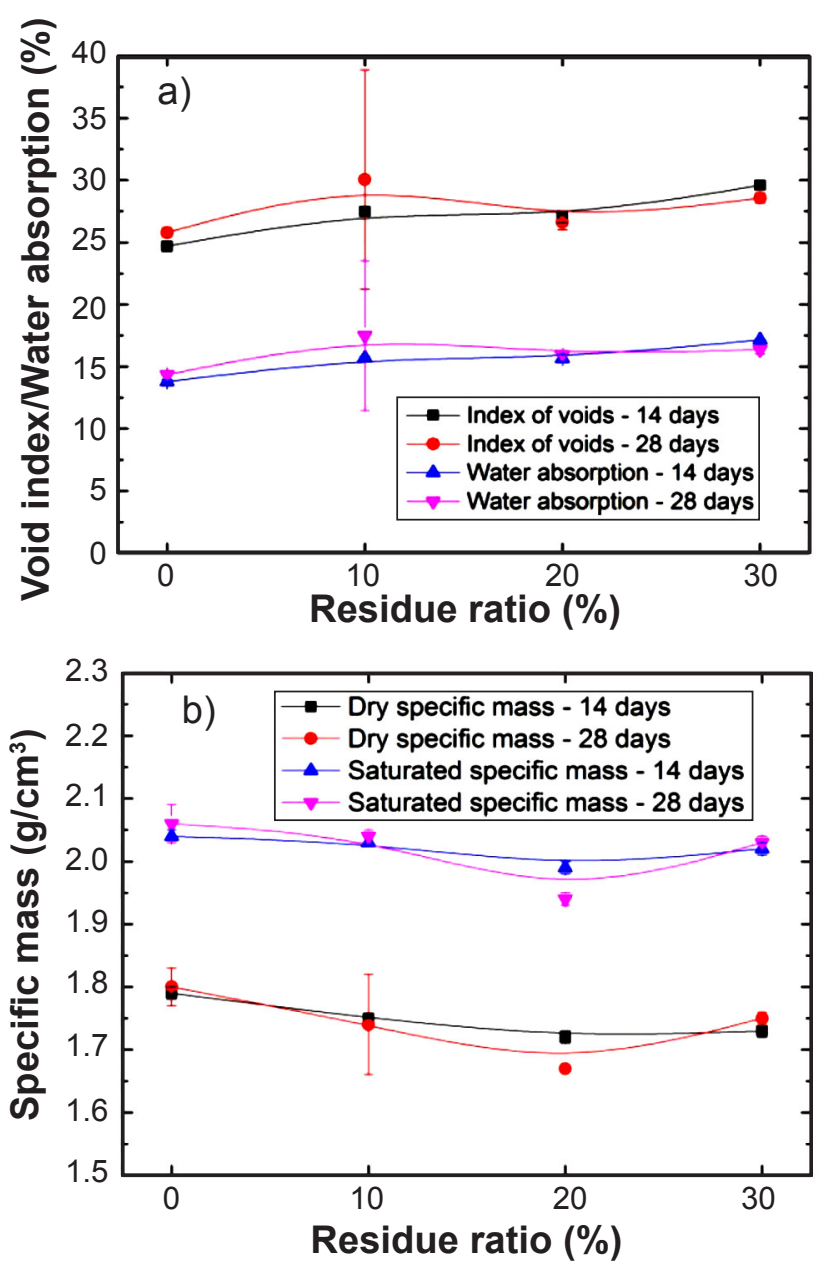

Figure 5: Void index and water absorption (a) and specific mass of dry and saturated test specimens (b).

containing $30 \%$ of gypsum and those without gypsum, at 14 days of curing, linear increases of approximately $17 \%$ and $20 \%$ in the voids index and water absorption, respectively, were noted, which indicated that the presence of gypsum in the mortars caused the amount of internal bubbles to increase. This can be explained by the fact that the consistency index increased along with the gypsum content, because of the higher this content the greater the moisture of the mortar, generating more bubbles during the casting process [27].
In Fig. 5b, the specific mass of dry $\left(\varrho_{d}\right)$ and saturated $\left(\varrho_{\text {sat }}\right)$ mortar test specimens at 14 and 28 days shows a slight linear reduction of approximately 5\% and $3 \%$ when one compares the specimens containing 30\% gypsum against those containing $0 \%$ waste. The values of dry and saturated specific mass ranged from 1.6 to $2.0 \mathrm{~g} / \mathrm{cm}^{3}$, respectively, corroborating the results of the calculated apparent density (Fig. 3), which was within an intermediate range.

\section{CONCLUSIONS}

According to SEM and EDS analyses, the gypsum powder waste used consisted of porous and irregular particles, free of impurities, with a lower density $\left(1.1 \mathrm{~g} / \mathrm{cm}^{3}\right)$ than ordinary sand and similar particle size distribution, which are favorable characteristics for its use in cement mortar mixes. The physical characterizations of the mortar test specimens indicated that this waste can be applied in the mix design of mortars in all the tested proportions, since the results of the flexural tensile and compressive strength tests exceeded the minimum values established by the NBR 13281 standard. In addition, the apparent density of the specimens containing $30 \%$ of gypsum replacing sand was approximately 5\% lower than that of the specimens without gypsum, which represents an advantage in the use of this waste in bricklaying and plastering walls and ceilings. Therefore, the proposed alternative not only contributes to reducing the disposal of gypsum waste in landfills but also allows it to be put to practical use without requiring calcination, contributing to the development of new material of added environmental value.

\section{ACKNOWLEDGMENT}

The authors gratefully acknowledge FAPESP for its financial support of this work.

\section{REFERENCES}

[1] Brasil, Lei n 12305, Diário Oficial, Brasília (2010).

[2] IPEA, "Diagnóstico dos resíduos sólidos da construção civil: relatório de pesquisa" (2012).

[3] B. Wedler, A. Hummel, Trümmerverwertung und Ausbau von Brandruinen, Wilhelm Ernest Sohn, Berlin (1946).

[4] CONAMA, Res. no 307 (2002).

[5] L.F. Bernhoeft, A.D. Gusmão, Y.V.P. Tavares, Amb. Constr. 11, 2 (2011) 189.

[6] O. Savio, in Proc. IX Enc. Tecnol. Eng. Civil Arquit., Maringá (2013) 145.

[7] ABRAGESSO, "Resíduos de gesso na construção civil: manuais técnicos" (2016).

[8] CONAMA, Res. n 431 (2011).

[9] A. Jiménez-Rivero, J. Garcia-Navarro, Resour. Conserv. Recycl. 116 (2017) 116.

[10] A. Erbs, A. Nagalli, V. Mymrine, K.Q. Carvalho, Cerâmica 61, 360 (2015) 482.

[11] Y.V.P. Tavares, A.C. Lordsleem Jr, I.B.T.A. Schmtz, 
V.M. John, Amb. Constr. 10, 1 (2010) 103.

[12] P.C. Guerrero, S.D. Mancini, C.M. Toubia, Holos Envir. 11, 2 (2011) 147.

[13] ABNT, NBR 7214, "Areia normal para ensaio de cimento", Rio Janeiro (2012).

[14] ABNT, NBR 16541, "Argamassa industrializada para assentamento de paredes e revestimentos de paredes e tetos: preparo da mistura para realização de ensaios', Rio Janeiro (2016).

[15] ABNT, NBR 7215, "Cimento Portland: determinação da resistência à compressão, Rio Janeiro (1996).

[16] ABNT, NBR 13276, "Argamassa para assentamento e revestimento de paredes e tetos: determinação do índice de consistência", Rio Janeiro (2005).

[17] ABNT, NBR 13279, "Argamassa para assentamento e revestimento de paredes e tetos: determinação da resistência à tração na flexão e a compressão", Rio Janeiro (2005).

[18] ABNT, NBR 13280, "Argamassa para assentamento e revestimento de paredes e tetos: determinação da densidade aparente no estado endurecido", Rio Janeiro (2005).
[19] ABNT, NBR 13281, "Argamassa industrializada para assentamento de paredes e revestimentos de paredes e tetos especificação", Rio Janeiro (1995).

[20] P.L.O. Costa Neto, Estatística, Edgard Blucher, S. Paulo (2002).

[21] A.N. Macêdo, A.M. Lima, F.O. Fonseca, B.V.A. Lavor, Rev. Matéria 16, 2 (2011) 658.

[22] ABNT, NBR 9778, "Argamassa e concreto: ensaio de determinação da absorção de água, índice de vazios e massa específica”, Rio Janeiro (2005).

[23] A.F. Battagin, R. Curti, C.O. Silva, F.A.C. Munhoz, in Proc. $44^{\text {th }}$ Congr. Bras. Concreto, Minas Gerais (2002) 2.

[24] C. Bezou, A. Nonat, J.C. Mutin, J. Solid State Chem. 117, 1 (1995) 165.

[25] H. Carasek, R.C. Araujo, O. Cascudo, R. Angelim, Rev. Matéria 21, 3 (2016) 714.

[26] A.M. Neville, J.J. Brooks, Tecnologia do concreto, Bookman, S. Paulo (2013).

[27] L.Z. D'Agostino, L. Soares, Geociências 22, 1 (2003) 65.

(Rec. 28/08/2018, Ac. 29/09/2018) 